\title{
THE GEOLOGY OF STELLWAGEN BANK
}

\author{
BY \\ ROBERT N. OLDALE ${ }^{1}$ \\ U.S. GEOLOGICAL SURVEY OPEN-FILE REPORT 94-672
}

This report is preliminary and has not been reviewed for conformity with U.S. Geological Survey editorial standards and stratigraphic nomenclature.

${ }^{1}$ U.S. GEOLOGICAL SURVEY

WOODS HOLE, MA 02543 


\section{LIST OF ILLUSTRATIONS}

Figure 1. Bathymetric map of Stellwagen Bank.

Figure 2. Oblique view of western Gulf of Maine.

Figure 3. Geologic cross section.

Figure 4. Glacial lobes.

Figure 5. Bottom sediment map of Stellwagen Bank. 


\section{THE GEOLOGY OF STELLWAGEN BANK}

BY

ROBERT N. OLDALE

\section{INTRODUCTION}

on a bathymetric map, a map showing lines of equal depth, (Fig. 1) the stellwagen Bank region of the Gulf of Maine appears to be a northward extension of outer cape cod and its adjacent sea floor. This is more than a coincidence, as the Bank and outer Cape cod share much of the same geologic history. The basic difference is that stellwagen Bank was submerged by the sea-level rise that followed the retreat of the last continental ice sheet. Cape cod remains above sea level, at least for the present. Both Cape cod and stellwagen Bank owe their present shapes to the last continental ice sheet of the Pleistocene Epoch (the ice age) and to associated changes in sea level.

Presently, stellwagen Bank is a submerged broad ridge or platform in the Gulf of Maine (Fig. 2), located about 42 kilometers (26 miles) east of Boston and about 10 kilometers ( 6 miles) north of the northern tip of cape cod. The bank forms a long narrow triangle, roughly 40 kilometers (25 miles) long. The southern end is about 16 kilometers (10 miles) wide, but it narrows to about 4 kilometers $(2.5$ miles) wide to the north. The surface of the bank is nearly flat and slopes gently eastward. Shallowest depths over the bank are about 20 meters (65 feet), but much of its western side is about 30 meters (100 feet) deep. 
The Bank is bordered to the west by stellwagen Basin and to the east by a deeper broad platform. The Bank rises about 49 meters (160 feet) above Stellwagen Basin and the deeper seafloor to the east.

The most important agent in the formation of the bank was the last continental ice sheet in North America. It is called the Laurentide ice sheet after the st. Lawrence region of Canada. This ice sheet formed about 75,000 years ago when less energy from the sun reached the Earth's surface than it does today. Variations in the amount of solar energy reaching the Earth's surface are caused by cyclical changes in the Earth's orbit around the sun and by cyclical changes in the inclination of the Earth's pole of rotation. Glaciers and ice sheets form when the climate is so cold more snow falls during the cold months than can melt during the warm months. Eventually, the lower part of this snow layer is compressed by its own weight into ice. over hundreds or thousands of years the ice becomes so thick it becomes plastic enough to flow. We call the mass of mobile ice a glacier or ice sheet. The Laurentide ice sheet covered all of Canada and much of the northern part of the United states east of the Rocky Mountains. In New England, the ice was thick enough to cover 6,000 foot high Mount Washington in New Hampshire. The Laurentide ice sheet reached southernmost New England about 21,000 years ago. The warmer climate there stopped the ice advance; its forward motion was balanced by melting along its southern margin. Shortly thereafter, the ice sheet began to 
retreat, as melting at its margin exceeded the rate of ice advance. By about 18,000 years ago the Laurentide ice sheet had retreated to the vicinity of what is now Cape cod and stellwagen Bank.

As ice sheets move forward (the flow of ice within an ice sheet continues even though its edge is retreating by melting) they plow and scrape up soil and loose sediment. They also grind away at the underlying bedrock surface and pluck away large fragments of the bedrock. These soil materials, sediments, and rock fragments are carried in the basal part of the ice sheet, but some may be plastered on the underlying surface or may be carried forward to be dumped at the ice margin. Sedimentary debris laid down directly by the ice is called glacial till. Till is unsorted and unlayered (unstratified), a mixture of all sizes and compositions of rock material from large boulders tc clay. Much of the rock material carried in the base of the ice sheet (gravel, sand, silt, and clay) is ultimately washed out by streams of glacial meltwater. These sediments are then called outwash. As the flow of meltwater changes, the outwash is sorted; the coarsest particles are deposited closest to the ice and the finest are deposited farthest away. Outwash is deposited in layers or strata and it is called stratified drift. The meltwater streams eventually reach lakes or the sea where they deposit sandy outwash in deltas along the shore. Muddy deposits (silt and clay) are carried away from the shore and deposited on the lake bottom or seafloor. 
The secondmost important agent in the construction of Stellwagen Bank was the sea, particularly its level relative to the surface of the Bank. Sea level changed markedly over the past 75,000 years. The Laurentide ice sheet and continental glaciers elsewhere on Earth, formed from moisture derived from the sea. This ice buildup lowered sea level around the world. Beyond the glacial margins, shorelines moved seaward and the shallow seafloor was exposed as coastal plains. At the maximum glaciation (about 21,000 years ago), the sea level fell to abcit 90 meters ( 300 feet) below its present level. Georges Bank (south of the Gulf of Maine) and the continental shelf south of New England were exposed. As the continental glaciers waned, water from their melting returned to the oceans, sea level rose, and parts of the coastal plains were again submerged. The sea level continued to rise until the shoreline reached its present position. Locally, sea-level change can be much more complex because the position of the shoreline depends not only on glokal (eustatic) sea level, but also on the vertical motion of the crust along the continental margins. For example, even though global sea level may be rising, the land may be rising even faster in some areas. In these areas, the local sea level would fall and the shoreline would move seaward. At various times in the past, sea levels have been both above and below present sea level, and ancient shorelines have migrated both landward and seaward of the present shoreline. The position of a sea level above or below present local sea level is called relative sea 
level. For example, along the northeast coast of Massachusetts, the relative sea level during late glacial times was more than 30 meters (100 feet) above present sea level, and the shoreline was well inland from the present shoreline. To the south, the crust (the outermost rock layer of the Earth) was depressed much less, because the glacial ice was thinner and the load on the crust much less. Thus, the late-glacial shoreline crossed the position of the present shoreline just south of Boston and is now submerged in the vicinity of cape cod and Stellwagen Bank. Stellwagen Bank formed along that now submerged late-glacial shoreline. In the Gulf of Maine, the great weight of the Laurentide ice sheet depressed the Earth's crust so that it was below global sea level. Therefore, as the ice sheet retreated from the Gulf of Maine, it was immediately flooded by sea water. Shortly after the ice sheet retreated from coastal New England, relative sea level began to fall, as, in response to the removal of the glacial load, the crust rose faster than eustatic sea level. For some time thereafter, the Bank remained above sea level, and it probably looked much like outer cape cod does today. However, eventually the crust slowed its upward rebound whereas eustatic sea level continued to rise, so that about 10,000 years ago the Bank was entirely submerged. These early changes in relative sea level were very rapid in a geological sense. Later, as all but two of the continental ice sheets (Greenland and Antarctica) melted (about 6,000 years ago) the rise in global sea level slowed and brought the bank to its 
present depth. Though sea level is still rising, the rate is only four inches every 100 years over Stellwagen Bank.

\section{THE FOUNDATION}

The geologic structure of Stellwagen Bank is shown by the cross section (Fig. 3). At depth, the bank rests on bedrock similar to that exposed along the New England coast from Plymorth northward, and which can be seen in road cuts and on hill sides in southern New England north of Cape cod. The bedrock surface is 120 to 180 meters ( 400 to 600 feet) below the top of Stellwagen Bank. Although we do not know the precise composition of the bedrock, we can make some reasonable assumptions. The bedrock probably is similar to rocks cropping out along the ccast of Massachusetts, which include igneous, sedimentary, and metamorphic varieties. The igneous rocks originally formed below the Earth's surface as a hot fluid mixture called magma. The magma may have cooled and solidified deep in the Earth's crust to form granite, or it may have reached the surface as lava flows, or in explosive volcanic eruptions (like Mount st Helens). Sedimentary rocks consist of numerous rock and mineral particles (sediment) that were deposited in stream beds, lakes, and seas. Types of sedimentary rock that underlie Stellwagen Bank probakly include conglomerate (mixtures of gravel and sand), sandstone, and shale (composed of silt and clay). Following their formation, many of the igneous and sedimentary rocks were altered by deep burial or by squeezing and folding during mountain 
building. The appearance and mineralogy of the original rock can be changed by heat and pressure, and such altered rocks are called metamorphic.

The bedrock beneath Stellwagen Bank is probably 150 to 500 million years old. The oldest bedrock formed before most of life as we know it today existed during a time that is known as the Precambrian. Other bedrock formed during the Paleozoic Era, when most of the life forms we know today first became abundant in the sea and later on the land. The youngest bedrock formed during the Mesozoic Era, the age of dinosaurs.

The bedrock contains a record of continents breaking apart and drifting away from each other to form ocean basins or colliding to form mountain ranges. Although we do not know for sure, it is likely that some of the bedrock beneath stellwagen Bank represents the time when the Atlantic Ocean first formed, about 200 million years ago. This occurred as North America, Europe, and Africa, which had previously collided to form the Appalachian Mountains, drifted apart again to form the Atlantic ocean.

THE COASTAL PLAIN

During the time between the opening of the Atlantic Ocean and the beginning of Pleistocene glaciation (the ice age), the Gulf of Maine, including the region of Stellwagen Bank resembled the present coastal plain from New Jersey to Virginia. The coastal plain forms the landward part of the continental margin 
that alternately emerges and submerges as sea level fluctuates. This plain is underlain by layers of mostly unconsolidated sedimentary rocks, which were deposited in rivers, swamps, and marshes, or on the shallow sea floor. The coastal plain deposits were formed between 5 to 140 million years ago during the last part of the Cretaceous Period (the latter part of the age of dinosaurs) and during the early part of the Tertiary Period (the age of mammals). During this long interval, coastal plain sediments completely filled the Gulf of Maine and buried the bedrock, including the present coastal region. The coastal plain was a generally flat, continuous, surface with a gentle seawart slope. It lay between the Fall Line (marked by the most seaward waterfalls on the rivers that enter the Gulf of Maine) and the seaward edge of Georges Bank that lies to the south of the Gulf. At times toward the end of the Tertiary Period, eustatic sea level was far below present sea level. During these times rivers and streams eroded the coastal plain strata in what is now the Gulf of Maine and began to shape stellwagen Bank. stellwagen Bank is thought to be constructed of ancient coastal plain strata between 75 and 120 meters (250 and 400 feot) thick (Fig. 3). These ancient coastal plain deposits may be loose gravel, sand, silt, and clay, similar to cretaceous and Tertiary deposits below Nantucket and Martha's Vineyard. Such deposits are now exposed in the Gay Head Cliff on the island of Martha's Vineyard. 


\section{GLACIATION}

The Pleistocene Epoch was characterized by alternating cold intervals of continental glaciation (glacial stages) and warm intervals (interglacial stages), when the continental glaciers shrank or melted away. In southern New England, there is abundant evidence of the Laurentide glaciation, but only sparse evidence of earlier glaciation. However, during the $1.6 \mathrm{million}$ years of the ice age, the Gulf of Maine was undoubtly glaciated many times. Glacial ice is the most powerful broad scale erosive force on Earth, so the continental glaciers that moved across the Gulf of Maine removed almost all of the coastal plain deposits and vast amounts of bedrock to finish what the late Tertiary streams had started.

The geologic history represented by the bedrock, coastal plain deposits, and earlier glacial deposits is incidental to the events that gave stellwagen Bank its present shape. These events include the Laurentide glaciation, the late-glacial marine incursion, and the changes in sea level that followed the retreat of the last ice. The combined glacial and postglacial deposits beneath Stellwagen Bank are up to 120 meters (400 feet) thick, but the glacial deposits make up, by far, the thickest portion (Fig. 3). These sediments overlie mainly the coastal plain deposits, but in a few places rest directly on bedrock. Although there are no boreholes in stellwagen bank to directly determine the nature of the glacial deposits, their composition and origin can be reasonably inferred from those of the outer cape cod 
glacial deposits. The distribution of glacial deposits on Car? Cod shows that during deglaciation the southern margin of the Laurentide ice sheet was lobate (Fig. 4). To the east of outer Cape cod was the South Channel lobe and to the west of outer cape Cod was the Cape cod Bay lobe. The relative ages of glacial units on Cape cod indicate that the lobes retreated at different times. The cape cod Bay lobe retreated away from the cape first and was replaced by a large glacial lake that occupied what is now Cape Cod Bay. The South Channel lobe retreated after the outer Cape cod outwash plains were formed by meltwater streams flowing westward from the south Channel lobe. When the meltwater streams reached the glacial lake they formed sand and gravel deltas along the lake shore and stream born silt and clay were carried into the lake and deposited on the lake floor. The sand and gravel accumulations along the lake shore, caused meltwater streams to lengthen which pushed the outer Cape cod outwash plains westward.

Using outer Cape Cod as an analogue for Stellwagen Bank we can infer a similar arrangement of ice lobes on either side of Stellwagen Bank. We can also infer, but with less confidence, that the Cape Cod Bay lobe had retreated somewhat from stellwagen Basin while the South Channel lobe remained in contact with the east flank of the bank. Layers of glacial mud containing marine fossils indicate that the ice-free part of Stellwagen Basin was occupied by an arm of the sea. In addition, organic carbon from the glacial mud in stellwagen Basin and fossil shells in 
Wilkinson Basin to the east of the bank, provide radiocarbon ages (based on ${ }^{14} \mathrm{C}$, a radioactive isotope of carbon that decays by half in 5730 years) help determine the age of cape cod and Stellwagen Bank. The most recent radiocarbon ages were determined from the shells of microscopic single celled animals called foraminifera, which lived in sea water and on the seafloor. When these animals died, their shells were incorporated in the glacial marine mud. The radiocarbon dates of these shells indicates that the sea had entered the basins by 18,000 years ago, and that stellwagen Bank was formed no later than that time.

The easterly slope of the bank top (Fig. 1) could be taken as evidence that the cape cod Bay lobe was the source of the outwash deposits. Other evidence indicates, however, that the South Channel lobe was a more likely source of the meltwater streams that supplied the sediments to build the bank. In stellwagen Basin, cores from the glacial marine mud, which was deposited during deglaciation, show that sediments are sandier toward the bank. Typically, meltwater deposits are coarser near the source and finer away from the source. This suggests that sandy outwash deposits entered the basin from the direction of the bank, which is east. Sediments on the eastern flank of Stellwagen Bank are even coarser (mostly gravel) (Fig. 5); thus it is most likely that the south Channel lobe that lay east of the bank was the source for the bank's glacial deposits. 
Gravel and coarse sand can be easily moved by fast strears, but much less easily in standing bodies of water, where currents are slow or absent. The glacial sand and gravel that make up Stellwagen Bank indicate that during the formation of the bank, the bank top was most likely above sea level. It is likely that the glacial deposits which built stellwagen Bank were deposited in a manner similar to that of the outwash on outer cape cod. Instead of meltwater streams carrying outwash into a glacial lake, however, they carried it to the sea that had entered Stellwagen Basin as the Cape cod Bay ice lobe retreated. Thus, like outer Cape Cod, stellwagen Bank is composed mostly of glacial stream deposits that overlie dipping prograding beds of deltas.

The glacial contribution to the formation of stellwagen Bank ceased once the South Channel ice lobe retreated from the eastern flank of the bank and into the Gulf of Maine. Removal of the ice load allowed the depressed bedrock to rebound causing sea level to fall some distance below the bank.

\section{CHANGING SEA LEVELS}

About 12,000 years ago, sea level in the southwestern part of the Gulf of Maine off Boston was about 50 meters (165 feet) below its present level, so that the top of stellwagen Bank stood well above the sea. The bank may even have had a dry land connection to lower cape cod or it may have been separated from the tip of Cape cod by a broad shallow strait in Little 
Stellwagen Basin. At that time, the top of stellwagen Bank probably looked very much like the glacial outwash plains of outer Cape cod, complete with kettle holes. Kettle holes formod where buried blocks of glacial ice melted and the overlying glacial outwash deposits collapsed into the melt cavity. Lakes, swamps, and marshes characterized the inland landscape of the bank. The seashore of the bank probably consisted of marine scarps or sea cliffs, bays closed off from the open sea by barrier beaches, coastal marshes, and sand dunes, such as we see along outer cape cod. The climate was much cooler than today, and the vegetation probably consisted of open park land covered by tundra shrubs and grasses and stands of spruce and poplar trees. Animals, including mastodon and mammoth, probably roamed across this landscape. This time was too early for ancient peoples to have completed their migration from Asia to New England. However, Paleoindians, who arrived in New England atsut 11,000 years ago, may have witnessed the next event that helped shape Stellwagen Bank.

The lowstand of relative sea level did not last long. Rebound of the crust slowed and global sea level rose rapidly as the continental glaciers, in full retreat, returned vast amounts of meltwater to the sea. About 10,000 years ago, sea level had risen high enough to drown stellwagen Bank. As the sea transgressed the bank, waves and currents eroded the upper layers of glacial sands and gravels and sorted and transported them across the bank top. In places only the sand was carried away 
from the glacial deposits leaving behind a concentration of gravel. Probably much of the gravel seafloor on the east flank of the bank formed in this way. Some of the sand was carried to the edge of the bank and deposited on the flank and in stellwagen Basin, where it covered the glacial marine mud. The present curve of the west flank may be the result of sand having been carried along the east and south sides of the bank by longshore currents, a current parallel to the shore generated by the oblique approach of waves. The sand then was deposited at the north and south ends of the bank to form recurved spits, like that which forms the tip of Cape cod. Today, even with the bank top at depths of 20 to 40 meters (65 to 130 feet), its surface remains sedimentologically active. Large storm waves, for example, move sand, and occasionally gravel, across the surface of the bank.

\section{THE FUTURE}

A few years ago an entrepreneur proposed to build a stiltlegged artificial island on Stellwagen Bank. On this island he planned to build a great resort, which would be the New England equivalent of Atlantic City, NJ. Although building the island may be structurally feasible, the plan showed an amazing lack of appreciation for the weather conditions on Stellwagen Bank, especially those of late summer, fall, and winter. Even if one was sheltered by steel, concrete, and glass, the bank would be a dangerous spot in a full-blown northeast storm or hurricane. 
Although the proposed artificial island may be a hairbrained scheme, interest in the bank's energy and mineral resources is not. There is little likelihood that oil and gas would be found beneath the bank because the coastal plain strata are too thin and the solid rock is likely not the type to contain these resources. However, it is not beyond the realm of possibility that an exploratory well will be proposed sometime in the future. The principal mineral resource is the sand and gravel of the bank. As the onland sources of these materials run out, attention could, and probably will, shift to offshore sites, such as Stellwagen Bank, to supply sand and gravel to Boston and other metropolitan areas along the Gulf of Maine coast of New England. Exploitation of the bank's sand and gravel resource may make economic sense. However, a clear understanding of the value of such mining activity balanced against the value of the bank's fishing resources and habitats for marine life (including marine mammals) will be necessary before any mining is initiated. Today's geological processes generate only subtle changes to the seafloor and the shape of the bank, compared to the past changes wrought by glaciation and sea-level change. Thus, humankind will probably see very little geological change on Stellwagen Bank. 


\section{FIGURE CAPTIONS}

Figure 1. Bathymetric map of the stellwagen Bank region showing Stellwagen Basin to the west of the bank, Stellwagen Bank, and part of outer cape cod. Contour interval, the vertical distance between lines of equal depth, is 10 meters ( 38 feet). One minute of latitude equals one nautical mile. Blue indicates areas covered by water; darker shades are deeper areas.

Figure 2. Computer generated oblique view of the western Gulf of Maine from Cape Cod to Cape Ann. Stellwagen Bank is located just north of outer Cape cod and Boston Harbor is in the upper left corner. Viewer is located south south east of Cape cod. Deepest water shown in blue, shallowest water in red. Approximate vertical exaggeration is 100X. Similar to an oblique aerial photograph, the horizontal and vertical scales are variable. Generated by Richard signell.

Figure 3. Geologic cross section of stellwagen Bank showing the bedrock (red), buried coastal plain strata (green), and glacial drift and postglacial marine deposits, undifferentiated (yellow). Vertical exaggeration about $33 \mathrm{X}$. Modified from U.S. Geological Survey Professional Paper 757. Figure 4. Inferred position of the Cape cod Bay and South Channel glacial lobes and the marine incursion during the formation of stellwagen Bank. Gray indicates location of the South Channel lobe (right) and the Cape cod Bay lobe 
(left), blue represents the late Wisconsinan marine incursion, and green represents dry land.

Figure 5. Sediment map of seafloor on Stellwagen Bank and vicinity. Modified from U.S. Geological survey Miscellaneous Geologic Investigations Map I-746. 


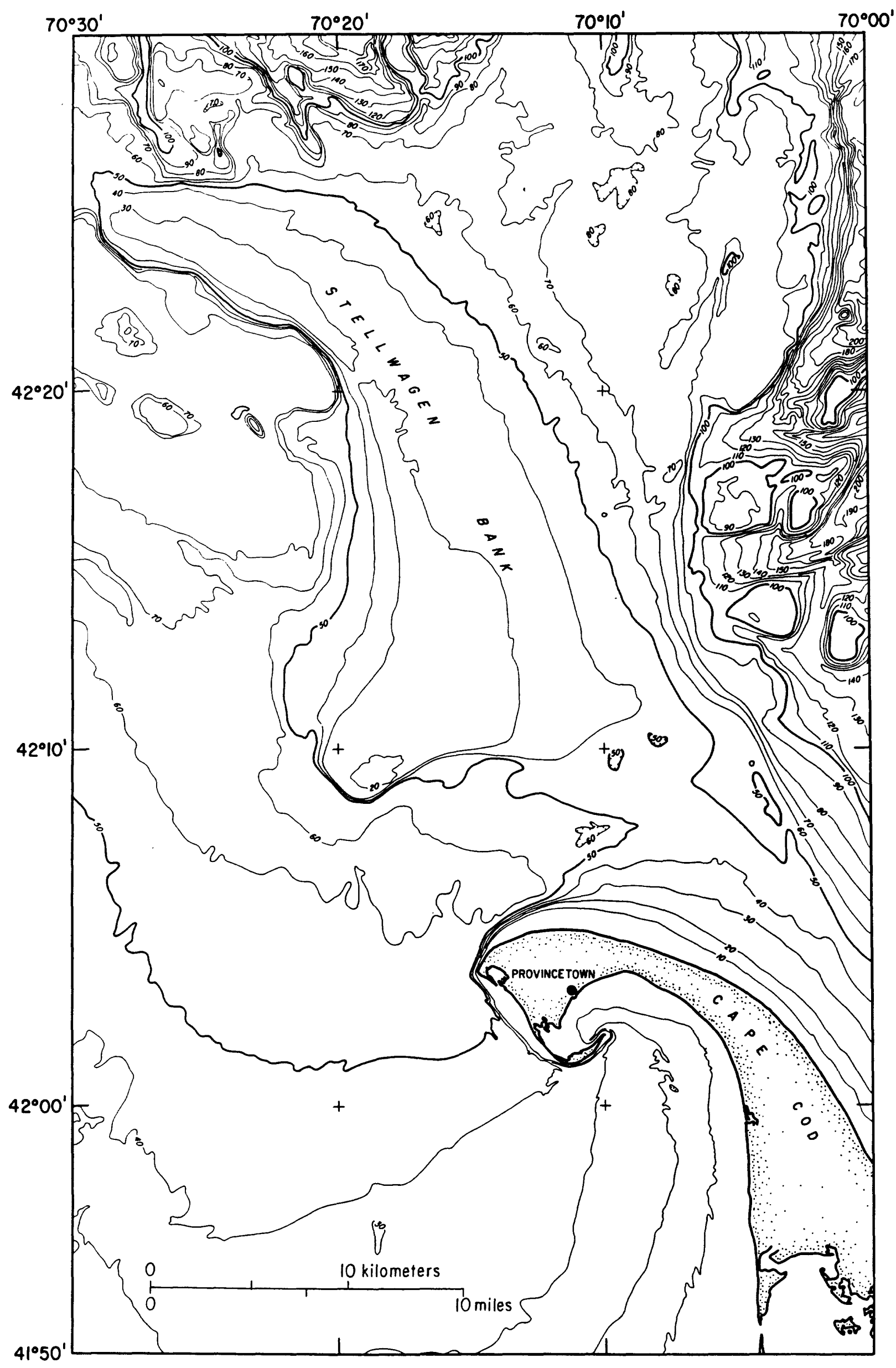




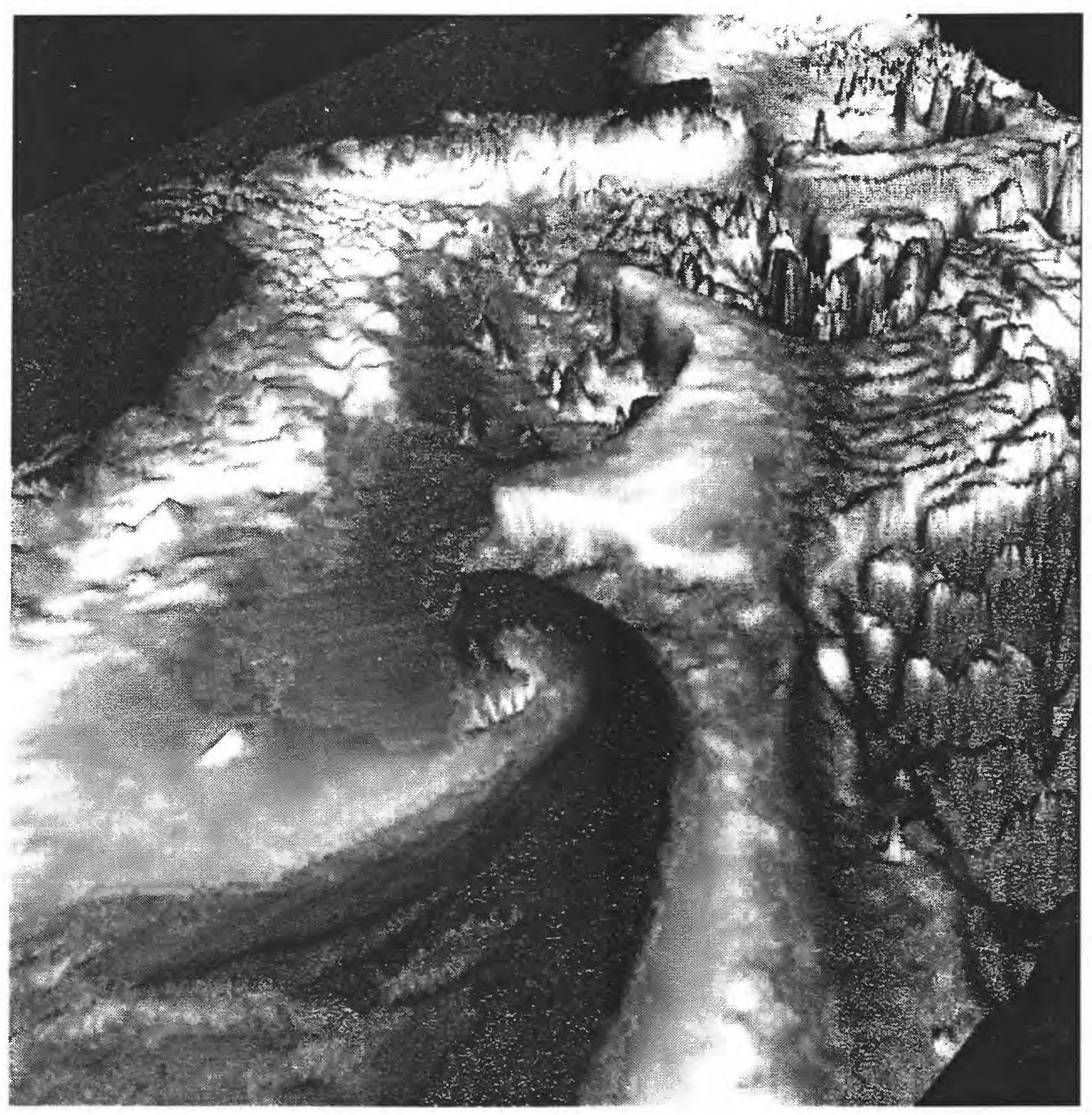




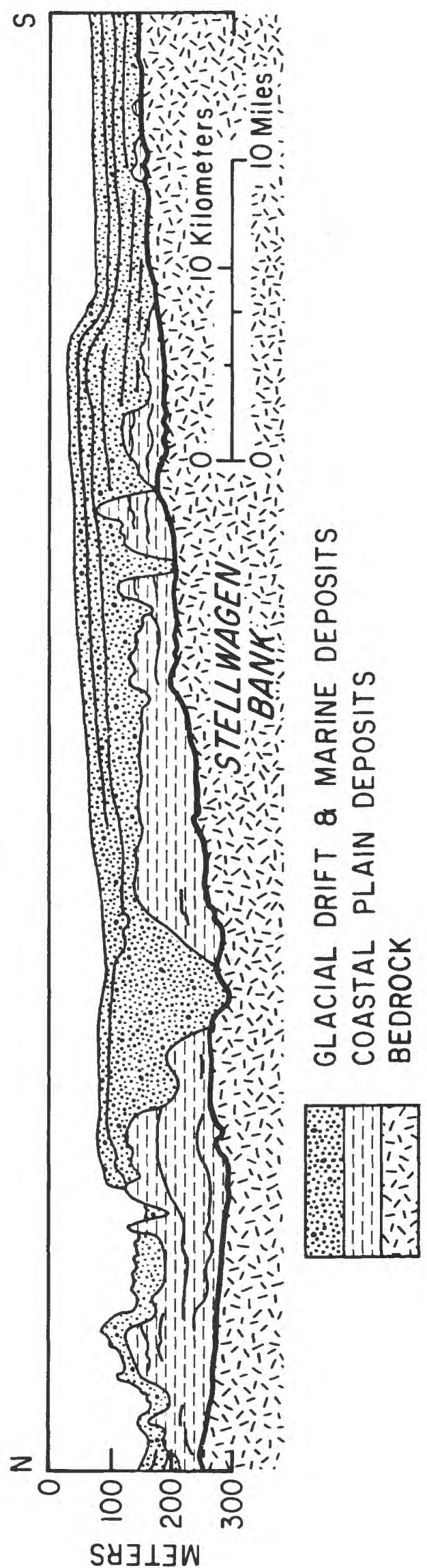




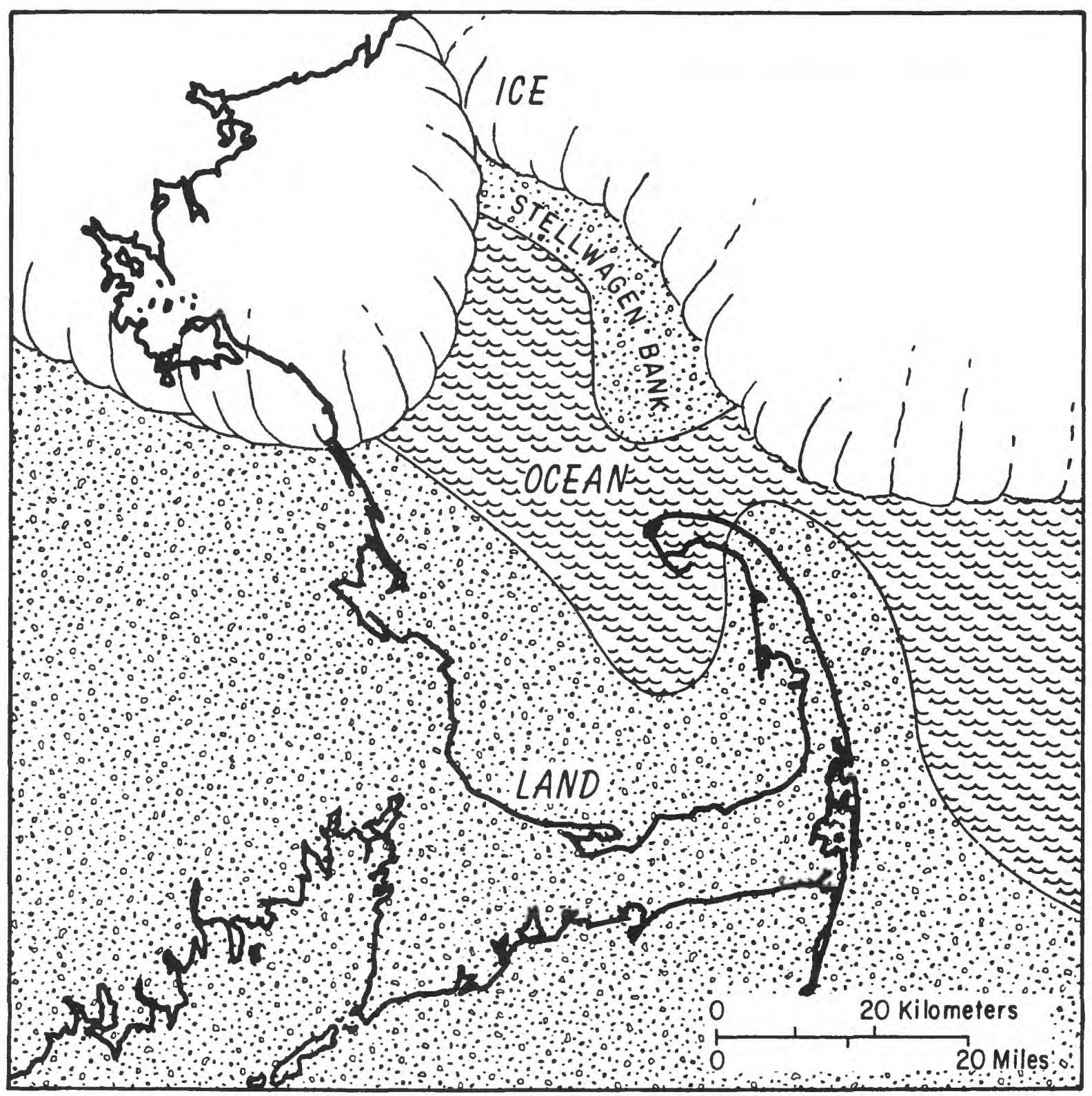




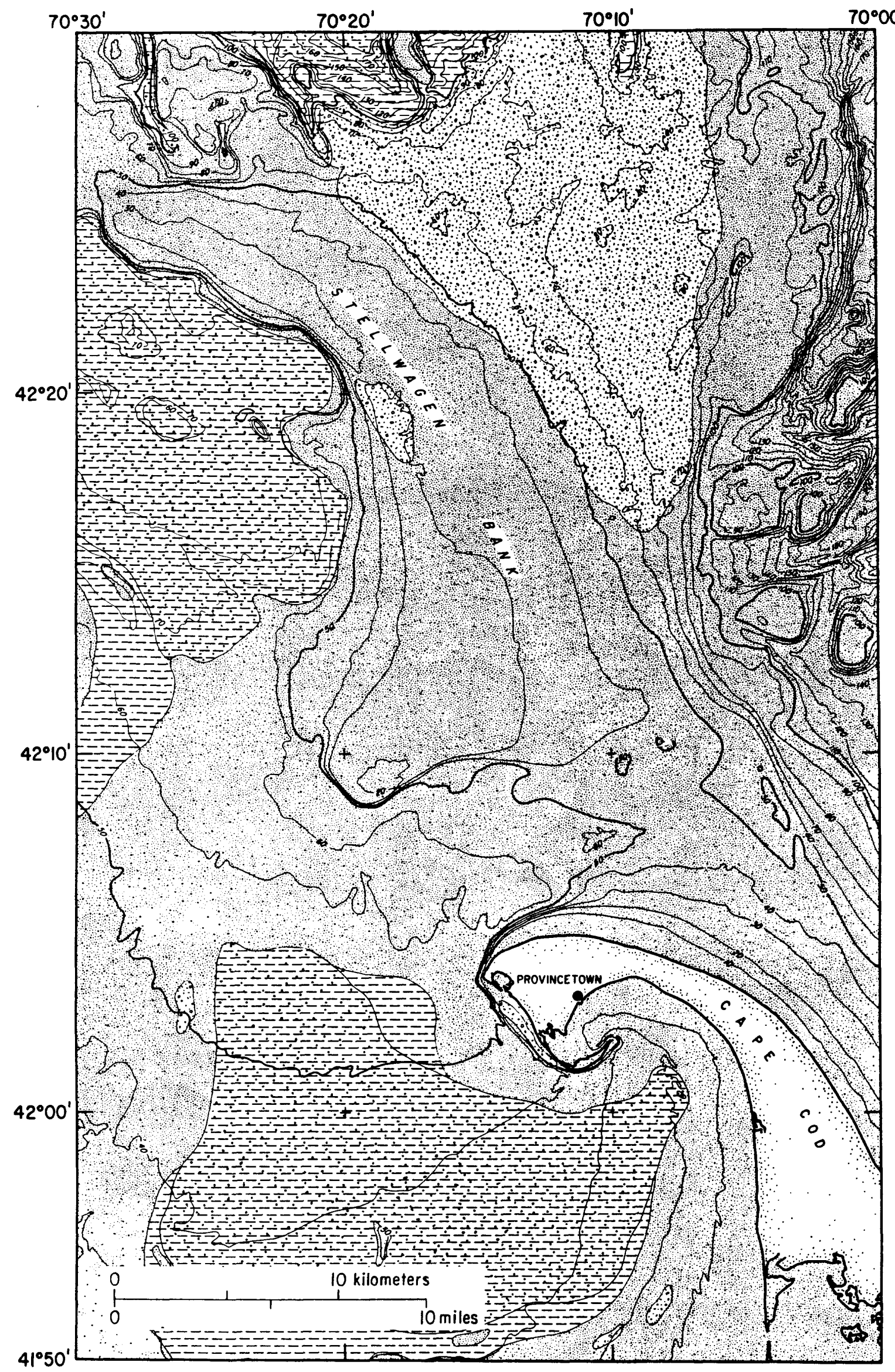

